\title{
Felon Disenfranchisement and Democratic Legitimacy
}

Forthcoming: Social Theory and Practice 43, no. 2 (2017)

\author{
Matt S. Whitt \\ Writing Sample
}

\begin{abstract}
Political theorists have long criticized policies that deny voting rights to convicted felons. However, some have recently turned to democratic theory to defend this practice, arguing that democratic self-determination justifies, or even requires, disenfranchising felons. I review these new arguments, acknowledge their force against existing criticism, and then offer a new critique of disenfranchisement that engages them on their own terms. Using democratic theory's "all-subjected principle," I argue that liberal democracies undermine their own legitimacy when they deny the vote to felons and prisoners. I then show how this argument overcomes obstacles that cause problems for other critiques of disenfranchisement.
\end{abstract}

In democratic societies where universal adult suffrage is the norm, policies that exclude individuals from the franchise deserve careful scrutiny. In the United States, citizens imprisoned on felony charges are almost always barred from voting in local, state, and national elections. ${ }^{1}$ Moreover, thirty-five out of fifty U.S. states practice some form of post-release felon disenfranchisement, meaning that many who have paid their debts to society in prison are nonetheless barred from the franchise until their suspension period ends. Even then, restoration can be obstructed by fees, resistant officials, and arbitrary procedures. ${ }^{2}$ In an era of so-called mass incarceration, felon and prisoner disenfranchisement policies prohibit a significant proportion of U.S. citizens - especially at state levels - from exercising their most fundamental political right. Given the disproportionate impact of policing and criminal conviction on nonWhites, historically marginalized groups are disenfranchised at especially alarming rates. ${ }^{3}$

\footnotetext{
${ }^{1}$ Maine and Vermont are outliers that do not restrict the voting rights of imprisoned persons with felony convictions.

${ }^{2}$ In Florida and Iowa, individuals must personally appeal for voting rights restoration. At the time of this writing, disenfranchisement laws in Virginia and Kentucky are being rewritten in contests between state legislators and executives, but neither state is considering reforms that eliminate post-release disenfranchisement.

${ }^{3}$ An estimated 5.3 million Americans of voting age are disenfranchised on the basis of present or past felony convictions; most of them are no longer serving time in jail or prison. This is more than 2 percent of the voting-age population, and is equivalent to more than 4 percent of the total number of voters in the 2012 U.S. presidential
} 
Not surprisingly, disenfranchisement policies have been the subject of much philosophical and legal criticism. Critics have argued that felon disenfranchisement is not justified by normative theories of punishment, nor by liberal social contract theory, nor by republican or communitarian theory. ${ }^{4}$ However, some political theorists and legal scholars have recently advanced a new wave of arguments in support of disenfranchisement. These arguments draw on democratic theory, rather than punishment or citizenship theory, to justify disenfranchising criminal offenders. Consequently, the new arguments are largely immune to existing criticism. In their basic form, these 'new wave' arguments maintain that democratic ideals of collective self-determination justify excluding some convicted felons from the electoral process. $^{5}$ Stronger versions claim that democratic self-determination actually requires disenfranchising felons or prisoners. ${ }^{6}$

Critics of disenfranchisement - even critics who invoke democratic theory to make their case- have not paid sufficient attention to these new arguments. Nevertheless, they deserve

election. However, disenfranchisement is geographically and demographically concentrated so that residents of some neighborhoods, municipalities, and states are impacted much more severely than others. Notably, about 8 percent of voting-age African Americans are formally disenfranchised and, in several southern states-Alabama, Kentucky, and Florida - one in every five adult African Americans is formally excluded from the franchise. Finally, these numbers tend to undercount the impact of disenfranchisement laws, because many ex-offenders who are eligible to have their rights restored do not seek restoration, often because of misinformation, bureaucratic hassle, or a lingering sense that their vote does not matter.

${ }^{4}$ Richard Lippke, "The Disenfranchisement of Felons," Law and Philosophy, 20 (2001): 553-580; Michael J. Cholbi, "A Felon's Right to Vote," Law and Philosophy, 21 (2002): 543-565; Pamela Karlan, "Retribution, Representation, and the Debate over Felon Disenfranchisement," Stanford Law Review, 56 (2004): 1147-1170; Jeffrey Reiman, "Liberal and Republican Arguments Against the Disenfranchisement of Felons," Criminal Justice Ethics, 24, no. 1 (2005): 3-18; Jason Schall, "The Consistency of Felon Disenfranchisement with Citizenship Theory," Harvard BlackLetter Law Journal, 22 (2006): 53-93; Nicholas Munn, "The Limits of Criminal Disenfranchisement," Criminal Justice Ethics, 30, no. 3 (2011): 223-239; Claudio López-Guerra, Democracy and Disenfranchisement: The Morality of Electoral Exclusion (Oxford: Oxford University Press, 2014).

5 Andrew Altman, "Democratic Self-Determination and the Disenfranchisement of Felons," Journal of Applied Philosophy, 22, no. 3 (2005): 263-273.

${ }^{6}$ Peter Ramsay, "Voters Should Not Be in Prison: The Rights of Prisoners in a Democracy," Critical Review of International Social and Political Philosophy, 16, no. 3 (2013): 421-438; Mary Sigler, "Defensible Disenfranchisement," Iowa Law Review, 99 (2014): 1725-1744. 
careful scrutiny not only because they are the most successful defenses of disenfranchisement in the theoretical literature, but also because they clearly articulate a normative claim that is often left implicit in policy debates about felon and prisoner voting, namely that electoral exclusion is justified in the name of democracy. This article seeks to critically examine that claim.

In this article, I overview the new defenses of disenfranchisement, acknowledge their force against existing criticisms, and then offer a critique that engages them on their own terms. Far from justifying felon disenfranchisement, I argue that fundamental democratic ideals motivate against this form of electoral exclusion. Using a modified version of democratic theory's "all-subjected principle," I argue that liberal democracies undermine their own legitimacy when they deny the vote to adults who are subject to democratic law. This includes convicted felons and individuals serving prison sentences. By perpetuating a class of adults who are governed by democratic law but barred from the political processes that generate, authorize, direct, and check that law, felon and prisoner disenfranchisement undermines the legitimacy of democratic decision-making. This, in turn, undermines democratic self-determination. Thus, the new defenses of disenfranchisement are self-defeating; they advocate policies which betray their own core commitments. Similarly, in the realm of public policy, when law-makers justify disenfranchisement in the name of democracy, their appeals ring hollow.

By showing how felon disenfranchisement undermines the legitimacy of democratic selfdetermination, my argument differs from critiques that emphasize how electoral exclusion harms disenfranchised persons. ${ }^{7}$ I do not take issue with those critiques, except to note that they have

\footnotetext{
${ }^{7}$ See for instance López-Guerra, Democracy and Disenfranchisement, Ch. 1, 3, 5. Much of López-Guerra's book is dedicated to explaining the injustice of selective disenfranchisement within typical liberal democratic voting systems. The innovative "enfranchisement lottery" argument of chapter 2 is separate from this work, and I do not engage it here. For a full treatment of that argument, see Jason Brennan's review of Democracy and Disenfranchisement in Social Theory and Practice 42, no. 1 (2016): 212-218.
} 
little bite against the new defenders of disenfranchisement, who might reply that disenfranchisement's harms to excluded individuals are outweighed by the benefits of democratic self-determination for the rest of the demos. To effectively respond to the new defenses of disenfranchisement, critics should resist opposing the claims of disenfranchised individuals to the claims of the demos that excludes them. In the argument advanced here, I align the claims of disenfranchised and enfranchised persons by arguing that disenfranchisement policies have an unacceptable cost for both disenfranchised felons and for enfranchised members of the demos. To reduce the claim to a bumper sticker, felon disenfranchisement undermines democratic legitimacy, and this negatively impacts all who are governed by democratic lawfelons and non-felons alike.

The article is structured as follows. In $\S 1$, I examine the 'new wave' defenses of felon disenfranchisement to show how they resist existing criticism of this practice. In $\S 2$, I look more closely at the appeal to democratic self-determination that underlies the new defenses of disenfranchisement. I argue that self-determination is always conditioned and limited by a deeper democratic commitment, the all-subjected principle, which states that all (adult, competent) persons who are subject to the law ought to be eligible to participate in the decision-making procedures that generate, direct, authorize, and check that law. ${ }^{8}$ Democratic legitimacy suffers when democracies disenfranchise individuals who, per the all-subjected principle, are entitled to political participation. Because this includes felons and prisoners, their disenfranchisement puts democratic legitimacy at risk. In $\S 3$, I consider a potential objection, namely that felons and prisoners might constitute reasonable exceptions to the all-subjected principle. I find that they do

\footnotetext{
${ }^{8}$ Robert Dahl provides a classic formulation of the principle in Democracy and its Critics (New Haven: Yale University Press, 1991), pp. 120-130. I follow Sofia Näsström in distinguishing the "all-subjected principle" from the more expansive "all-affected principle." Näsström, "The Challenge of the All-Affected Principle," Political Studies, 59 (2011): 116-134.
} 
not. In $\S 4$, I argue that the new wave defenses of disenfranchisement undercut themselves by sacrificing the core political good-democratic self-determination-on which they are based. I also show how my argument overcomes an unacknowledged problem with other recent critiques of disenfranchisement, like those offered by López-Guerra. In $\S 5$, I conclude by arguing that felon and prisoner disenfranchisement negatively impacts not only the persons who are excluded from the demos, but also the demos itself.

\section{§1. 'New wave' defenses of felon disenfranchisement}

Until recently, the theoretical consensus has opposed felon disenfranchisement, and strong defenses were absent from the literature. As one study surveyed the field in 2006, "Critics of disenfranchisement may feel a bit like a boxer entering the ring only to find that there is no opponent to fight." "It may be more apt to say that the ring had begun to get crowded, but with allies rather than opponents, as critics lined up against disenfranchisement policies. Within this consensus, the most powerful critiques have generally taken one of two approaches: arguing that disenfranchisement is an illegitimate form of punishment, or arguing that disenfranchisement violates widely-held commitments about citizenship.

Examining disenfranchisement as a punitive practice, Pamela Karlan has argued that it cannot be justified by any normative theory of punishment. ${ }^{10}$ Disenfranchisement does not deter crime; nor does it help rehabilitate former offenders or incapacitate likely offenders. It might be justified on retributivist grounds, but even this fails, because disenfranchisement imposes excessive and temporally open-ended losses not only on offenders but also on their communities,

\footnotetext{
${ }^{9}$ Jeff Manza and Christopher Uggen, Locked Out: Felon Disenfranchisement and American Democracy (Oxford: Oxford University Press, 2006), p. 12.

${ }^{10}$ Karlan, "Retribution, Representation, and the Debate over Felon Disenfranchisement."
} 
and this violates retributivism's commitment to proportional punishment. Karlan concludes that disenfranchisement is an essentially illegitimate form of punishment. Other scholars have conceded that disenfranchisement might be a legitimate form of punishment in principle, but background injustices in real-life societies make it illegitimate in practice. ${ }^{11}$

Recognizing that courts generally do not consider disenfranchisement to be a form of punishment, other theorists have turned to citizenship theory to criticize existing policies. Here too, disenfranchisement policies have been found to lack justification within prevailing normative frameworks. On one hand, republican theories of citizenship stress the need for a minimum of civic virtue among the individuals who participate in the political process, and this would seem to provide an intuitive justification for disenfranchisement. However, the justification does not bear scrutiny, because republican theorists are unable to show that convicted felons necessarily lack the requisite virtue, or that enfranchised non-felons necessarily possess it. $^{12}$ On the other hand, liberal citizenship theory would appear to legitimate disenfranchisement as a consequence of violating the social contract. However, felony offenses are not tantamount to withdrawing consent from the social contract, because law-breaking does not imply a denial of the law's authority. Moreover, even when someone can be said to violate the contract, Jeffrey Reiman has argued that this does not justify stripping the offender of all political rights, or voting rights in particular, except in special cases when the death penalty is a permissible sanction - if indeed there are such cases. ${ }^{13}$ Thus, neither republican nor liberal citizenship theory justifies felon disenfranchisement as it is currently practiced. In fact, some

\footnotetext{
${ }^{11}$ Lippke, "The Disenfranchisement of Felons;" Reiman, "Liberal and Republican Arguments Against the Disenfranchisement of Felons;" Munn, "The Limits of Criminal Disenfranchisement."

${ }^{12}$ Reiman, "Liberal and Republican Arguments Against the Disenfranchisement of Felons," p. 8.

${ }^{13}$ Ibid., pp. 10-11.
} 
critics have argued that republican and liberal theories of citizenship offer reasons for protecting the voting rights of convicted felons. ${ }^{14}$ Looking beyond republican and liberal frameworks, Katherine Pettus and Andrew Dilts have critiqued felon disenfranchisement for dividing an ostensibly equal and unified citizenry against itself, enabling enfranchised citizens to dominate disenfranchised felons and the social groups to which they belong. ${ }^{15}$

Although the theoretical consensus has been hostile to felon disenfranchisement with regard to punishment theory and citizenship theory, defenders of disenfranchisement have recently turned to democratic theory to justify the practice. According to this approach, disenfranchisement is not a form of punishment, nor a mode of regulating citizenship, but a tool for collective political self-determination. This line of defense has generally gone unchallenged by critics. Its strength lies not only in its appeal to widely held democratic principles, also in the widespread assumption that democracy justifies, or even requires, a bounded political association circumscribed by electoral exclusion.

Among its fundamental normative commitments, democratic theory contends that the members of a democratic political association - a demos - have a right to collective selfdetermination. ${ }^{16}$ This includes deciding on the processes by which democratic decisions are made and the regulations concerning who may participate in those processes. As Andrew Altman puts it, "The citizens of a legitimate democratic state have a broad collective right to order their

\footnotetext{
${ }^{14}$ Ibid., p. 14; López-Guerra, Democracy and Disenfranchisement, pp. 110-113.

${ }^{15}$ Katherine Irene Pettus, Felony Disenfranchisement in America: Historical Origins, Institutional Racism, and Modern Consequences, second edition (Albany, NY: SUNY Press, 2013); Andrew Dilts, Punishment and Inclusion: Race, Membership, and the Limits of American Liberalism (New York: Fordham University Press, 2014).

16 "The idea of democracy derives its power and significance ... from the idea of self-determination; that is, from the notion that members of a political community - citizens - should be able to choose freely the conditions of their own association, and that their choices should constitute the ultimate legitimation of the form and direction of their polity." David Held, Democracy and the Global Order (Stanford: Stanford University Press, 1995), p. 145. See also Dahl, Democracy and its Critics, pp. 89-90.
} 
own affairs as they choose. ... [A]s a way of defining the political identity of their community, citizens have a collective right to disenfranchise those duly convicted of such [serious] crimes."17 At this fundamental level, democratic theory appears to support the right of citizens to adopt disenfranchisement policies as they see fit, so long as they do so through legitimate democratic processes.

Of course, there are limits to the decisions a demos might legitimately make in the name of self-determination. However, it seems plausible that voting rights are indeed the kinds of rights that may be legitimately restricted or suspended by a demos, at least in certain cases. Richard Arneson and Claudio López-Guerra have persuasively argued that voting rights are neither fundamental nor inviolable, while David Miller has argued that the right to vote is a conditional human right that may be forfeited if one commits certain kinds of criminal acts. ${ }^{18}$ Side-stepping a complex debate about the nature of political rights, we can accept for the sake of argument that voting rights are neither inviolable nor unconditional human rights. Granting that the right to vote can in principle be restricted or suspended, the question becomes whether democratic self-determination warrants doing so with regard to criminal offenders, as Altman claims.

The arguments that I am calling 'new wave' defenses of disenfranchisement all answer this question in the affirmative. In addition to Altman's defense, stronger versions hold that democratic self-determination not only allows, but in fact requires the disenfranchisement of

\footnotetext{
${ }^{17}$ Altman, "Democratic Self-Determination and the Disenfranchisement of Felons," pp. 264, 267. Altman acknowledges that this collective right to self-determination may be restricted by other commitments, but recognizes felon disenfranchisement as a legitimate means of self-determination.

${ }^{18}$ Richard J. Arneson, "On the Supposed Right to a Democratic Say," in Contemporary Debates in Political Philosophy, edited by Thomas Christiano and John Christman (Malden, MA: Wiley-Blackwell, 2009), pp. 197-212; López-Guerra. Democracy and Disenfranchisement, pp. 15-17, 162.
} 
prisoners and felons. For instance, Peter Ramsay argues that currently incarcerated felons must be excluded from the franchise in order to preserve the integrity of democracy. In his view, genuinely democratic self-government requires that voters be free to debate, deliberate, assemble, express their political views, and cast their votes with minimal intrusion from the government. However, incarcerated individuals lack these freedoms, since their political activity is directly restricted by the state. Thus, to allow them to vote would at best grant them a formal but meaningless right. At worst, it would provide an avenue for the government to unduly influence elections. Therefore, according to Ramsay, prisoner disenfranchisement is necessary to protect "the formal integrity of the democratic process." 19 Although he rejects post-imprisonment disenfranchisement policies, Ramsay concludes that democratic self-determination requires disenfranchising currently incarcerated prisoners.

The most developed example of this new argumentative strategy is Mary Sigler's argument for "defensible disenfranchisement." Acknowledging that disenfranchisement cannot be justified as a form of punishment or civic excommunication, Sigler conceptualizes the practice as "a means of regulating electoral eligibility" by temporarily suspending the voting rights of citizens who "have violated the civic trust that makes liberal democracy possible." ${ }^{20}$ In her view, serious criminal misconduct represents a breach of trust because it involves "flouting the laws collectively established for our mutual benefit." ${ }^{21}$ To formally mark this breach, a citizen convicted of a serious felony should be made to "sit out the vote until he can reestablish the presumption of trust formally called into question by his criminal act."22 Although the period

\footnotetext{
${ }^{19}$ Ramsay, "Voters Should Not Be in Prison," p. 422.

${ }^{20}$ Sigler, "Defensible Disenfranchisement," p. 1728.

${ }^{21}$ Ibid., p. 1737.

${ }^{22}$ Ibid., p. 1738.
} 
of disenfranchisement will vary, Sigler recommends that most felons be barred from voting for four years - one full U.S. presidential election cycle — after which time their voting rights may be restored. This short-term electoral exclusion simultaneously marks the breach in civic trust and reaffirms the basic norms of the community, but it does not constitute the "hard treatment" that typically characterizes punishment. ${ }^{23}$

Despite their differences, these 'new wave' defenses of disenfranchisement all share a core argumentative strategy. Shifting the debate away from questions concerning what democratic societies may permissibly do to individuals, they instead focus on how democratic societies are entitled to define themselves through collective self-determination. ${ }^{24}$ Avoiding simplified accounts of unlimited democratic self-determination, the new wave arguments maintain that democracies have the right-and perhaps the obligation - to disenfranchise specifically those individuals who have seriously violated the law. This new argumentative strategy has three important consequences for theoretical debate.

First, by conceptualizing disenfranchisement as a form of self-determination, the new arguments put disenfranchisement policies beyond the reach of existing criticism. Since disenfranchisement is not a form of punishment, it need not deter crime or maintain proportionality; since it is not a way of regulating citizenship, it need not reflect the accepted norms of citizenship theory. Thus, existing critiques have little bite. Moreover, by justifying

\footnotetext{
${ }^{23}$ On punishment as hard treatment, see Joel Feinberg, Doing and Deserving: Essays in the Theory of Responsibility (Princeton: Princeton University Press, 1970), pp. 95-8 and Thom Brooks, Punishment (New York: Routledge, 2012), pp. 101-122. Jean Hampton offers a limited defense of disenfranchisement that is similar to Sigler's; I critique both arguments together in $\S 3$. See Hampton, "Punishment, Feminism, and Political Identity: A Case Study in the Expressive Meaning of the Law," Canadian Journal of Law and Jurisprudence 11, no. 1 (1998): 23-45.

${ }^{24}$ The new defenses of disenfranchisement all draw their force from a general, widely-held commitment to democratic self-determination, which is also invoked in other contexts (for example, debates about immigration) to justify political exclusion. However, they invoke self-determination in different ways. Because of their differences, I critique each of the arguments separately in $\S 3$.
} 
electoral exclusion in the name of democracy, the new defenses motivate a widely held set of ideals to insulate themselves from any forthcoming critiques based in punishment theory or citizenship theory.

Second, the new arguments cleanly separate arguments for criminal sanctions from arguments for disenfranchisement, thereby dividing justificatory work across theoretical frameworks, instead of trying to pull too much out of any one theory. While punishment theory may (or may not) justify imprisoning offenders, restricting their rights to movement, assembly, and speech, it is democratic theory that, according to the new wave arguments, justifies disenfranchisement. Although the arguments target only a particular class of individuals - those who have been convicted of serious legal offenses - the appeal to democratic self-determination allows the new wave defenders to remain agnostic about the right approach to punishment or other criminal justice policies.

Third, and most importantly, the new wave arguments shift the terrain of debate from individualist reasons to collectivist ones. By citing a powerful collective good-democratic selfdetermination - to justify disenfranchisement, the new arguments deflect critiques that appeal to the interests, claims, or rights of disenfranchised individuals. For instance, Claudio LópezGuerra has recently argued that disenfranchisement unjustly harms the individuals who are excluded from the franchise by unfairly depriving them of an important political good and by expressing unwarranted forms of disrespect. ${ }^{25}$ However, the new defenders of

\footnotetext{
${ }^{25}$ Democracy and Disenfranchisement, pp. 21, 71, 109-132. In arguing that convicted felons do not deserve disenfranchisement, López-Guerra does not imply that they do not deserve punishment or other forms of censure. However, like Karlan and others, he argues that disenfranchisement is a disproportionate and unjust consequence for most criminal offenses (115-116). Taking moral desert seriously, in other words, generally rules out disenfranchisement, although there may be some offenses, such as treason or electoral fraud, where offenders more clearly deserve electoral exclusion. Rather than pursuing this issue, I shift away from questions of individual desert to questions of wider social and political impact, to meet the new wave arguments on their own terms.
} 
disenfranchisement can bite the bullet and appeal to the 'greater good' of democratic selfdetermination in order to justify some harm to excluded individuals. In fact, Altman, Ramsay, and Sigler make three argumentative moves that, taken together, constitute a comprehensive reply to López-Guerra. First, they claim that some harm to offenders is justified by their past actions; second, they argue that this harm is outweighed by the importance of democratic selfdetermination and its benefits for the entire demos; and third, they introduce provisions to ensure that the harms of disenfranchisement are not excessive. In addition to deflecting López-Guerra's critique, this strategy leads debate to an argumentative impasse, in which there is no uncontroversial way to adjudicate between the collectivist reasoning of disenfranchisement's defenders and the individualist reasoning of its critics. Any critique of disenfranchisement that focuses solely on the well-being or moral claims of disenfranchised individuals, without adequately acknowledging the claims of the enfranchised members of the demos, will run headlong in to this impasse. ${ }^{26}$

For all of these reasons, the new wave arguments present an innovative and thorny challenge to philosophical critics of disenfranchisement. In the next section, I take up this challenge by engaging the arguments in their own terms. Instead of focusing on what disenfranchised individuals deserve, or on how electoral exclusion harms them, I focus on what disenfranchisement does to democracy itself. I argue that felon and prisoner disenfranchisement

\footnotetext{
${ }^{26}$ The same impasse appears in the philosophical literature on immigration. On one side, open-border advocates like Joseph Carens offer individualist, broadly Kantian reasons for including immigrants in a particular polity; on the other side, advocates of discretionary immigration controls, like David Miller, offer collectivist, broadly Hegelian reasons excluding at least some immigrants. As with the 'new wave' defenses of disenfranchisement, defenders of discretionary immigration controls sometimes appeal to collective self-determination to trump individual claims to inclusion. The impasse deepens as the two sides of the debate pass the burden of argument back and forth. See David Miller, National Responsibility and Global Justice (Oxford: Oxford University Press, 2007), pp. 67-80, 223224 and "Immigrants, Nations, and Citizenship," Journal of Political Philosophy, 16, no. 4 (2008): 371-390; Joseph Carens, The Ethics of Immigration (Oxford: Oxford University Press, 2013), pp. 262-270. For a comprehensive overview of the debate, see Sarah Fine, "The Ethics of Immigration: Self-Determination and the Right to Exclude," Philosophy Compass, 8, no. 3 (2013): 254-268.
} 
erodes democratic legitimacy, and this negatively impacts all persons who are governed by democratic law_felons and non-felons alike-regardless of their eligibility to vote. Because Altman, Ramsay, and Sigler defend disenfranchisement in the name of democracy, this erosion of democratic legitimacy presents a serious problem for their arguments.

\section{§2. Self-determination and the all-subjected principle}

The 'new wave' defenses of disenfranchisement rely upon a powerful political ideal: the prerogative of a democratic people to collectively determine the conditions of its own political association. But this prerogative cannot be invoked to legitimate just any act of political selfdefinition. This is partly because other political ideals, like respect for human rights, condition the right to self-determination. ${ }^{27}$ But it is also because democratic self-determination itself has normative limits that constrain a demos from defining its membership in particular ways. Once we acknowledge these limits, we will see that the ideal of democratic self-determination in fact cuts against the very policies that Altman, Ramsay, and Sigler defend. Rather than justifying felon and prisoner disenfranchisement, the commitment to democratic self-determination invalidates these forms of electoral exclusion.

To see this, theorists should ask who is the collective 'self' of self-determination. Who is included in the demos that rules itself and defines itself in a democracy? These are important normative questions. It is uncontroversial that democracy requires appropriate decision-making procedures, such as voting, if it is to do the normative work that its advocates claim for it, such as generating binding laws or justifying policies to the individuals governed by them. But for the same reason, democracy also requires appropriate ways of defining the demos that participates in

\footnotetext{
${ }^{27}$ Allen Buchanan, Justice, Legitimacy, and Self-Determination (Oxford: Oxford University Press, 2004).
} 
these decision-making procedures. ${ }^{28}$ If the demos is insufficiently inclusive, representative, or competent, then its decisions will lack legitimacy. As generations of democratic reformers have claimed, a 'democracy' that enfranchises only select individuals on a morally unjustified basisWhite male property owners, for instance - is not a genuine democracy, even if those in the demos do rule themselves through democratic decision-making. ${ }^{29}$ To be legitimate, democratic self-determination requires appropriate procedures for making collective decisions and an appropriately constituted decision-making body.

Democratic theory offers a fundamental and intuitive baseline for assessing whether a demos is sufficiently inclusive to legitimize its collective decisions. This is the "all-subjected principle" of democratic inclusion, which states that all persons subject to the law have a prima facie claim to participate in the decision-making processes that create, authorize, direct, and check that law. Robert Dahl succinctly formulates the all-subjected principle, and its typical exceptions, like so: "The demos should include all adults subject to the binding collective decisions of the association... except transients and persons proved to be mentally defective."30 This principle should not be confused with the "all-affected principle," which theorists have critiqued for being too vague or expansive to indicate a particular demos. ${ }^{31}$ The all-subjected principle is more restricted. To be subject to the law is to be affected in a particular way; it is to

\footnotetext{
28 "Like the constitution of government, the constitution of the people raises a claim for legitimacy." Sofia Näsström, “The Legitimacy of the People," Political Theory, 35, no. 5 (2007): 624-658 at p. 626.

${ }^{29}$ Dahl, Democracy and its Critics, pp. 121-2. López-Guerra has argued that democratic legitimacy does not require universal suffrage, but he is clear that a less-than-universal constituency must be genuinely representative of the entire population. Democracy and Disenfranchisement, Ch. 2.

${ }^{30}$ Dahl, Democracy and its Critics, pp. 120, 129. Notably, the all-subjected principle applies to some individuals who are not citizens, such as permanent residents. Throughout, I follow the literature on felon disenfranchisement in assuming that the felons and prisoners in question are adult citizens, who would otherwise have the right to vote.

${ }^{31}$ For critiques of the all-affected principle, see Robert Goodin, "Enfranchising All Affected Interests and its Alternatives," Philosophy and Public Affairs, 35, no 1 (2007): 40-68; Näsström, "The Challenge of the All-Affected Principle;" Zoltan Miklosi, "Against the Principle of All-Affected Interests," Social Theory and Practice, 38 . no. 3 (2012): 483-503.
} 
have one's behavior or status governed by law on a regular and ongoing basis, with the coercive power of the state standing behind the law. ${ }^{32}$ According to the all-subjected principle, the individuals who are subject to the law in this way ought to be eligible to participate in the democratic decision-making that generates, directs, and checks the law. As I will discuss below, some exceptions to the rule may be independently justified (for example, for young children or non-citizen tourists). ${ }^{33}$ However, if a demos generally fails to meet the threshold stipulated by the all-subjected principle, its acts of self-determination will lack legitimacy, potentially to a very significant extent.

The force of this principle derives from the fundamental insight that a legitimately authoritative government cannot treat its subjects as mere objects of administrative power. Rather, it must give equal consideration to their diverse liberties, goods, and preferences, and it must do so while respecting their moral autonomy. In democracies, this is done by making them eligible for indirect self-legislation. ${ }^{34}$ In societies where voting is the institutionalized means of self-legislation, the core insight of the all-subjected principle is clear: with some justified exceptions, all persons subject to the law ought to be eligible to vote. If they are not, democratic legitimacy suffers.

Robert Dahl makes this point forcefully against Joseph Schumpeter's claim that every democratic society has the prerogative to exclude from the franchise whomever it wishes, so

\footnotetext{
${ }^{32}$ Beckman, The Frontiers of Democracy, pp. 47, 50; López-Guerra, Democracy and Disenfranchisement, p. 97.

${ }^{33}$ In $\S 3$, I consider whether felons and prisoners are justifiable exceptions to the principle. I argue that they are not.

${ }^{34}$ The all-subjected principle appears in different forms in different philosophical frameworks. For instance, John Rawls articulates it as a "principle of (equal) participation" while Jürgen Habermas articulates it as a "principle of democracy," and while both philosophers nuance the principle to accommodate their different theories, the basic normative core remains the same. Rawls, A Theory of Justice, Revised Edition (Cambridge: Belknap Press, 1999), p. 194; Habermas Between Facts and Norms (Boston: MIT Press, 1998), 120.
} 
long as the society collectively affirms its reasons for doing so. ${ }^{35}$ Dahl rightly points out that on this view, we might criticize southern U.S. states during the Jim Crow era for a variety of injustices, but it would be inaccurate to describe them as undemocratic, so long as their disenfranchisement of African Americans was internally justified among the power-holding demos. But this is absurd; "surely to that extent the South was undemocratic: undemocratic in relation to its black population." ${ }^{36}$ It is easy to mistake Dahl's point. Alongside the powerful injustices done to African Americans through their electoral exclusion (such as discrimination, disrespect, deprivation, marginalization, and other harms), Dahl maintains that there is another, different kind of problem here - a problem not of liberal or egalitarian justice, but of democracy itself. He writes, "Is there not some number or proportion of a population below which a 'people' is not a demos but rather an aristocracy, oligarchy, or despotism?"37 Regardless of whether a particular society hits that tipping point, the problem is that a democracy that excludes qualified subjects from its demos narrows its own basis of legitimacy. In so doing, it undermines its own democratic credentials.

None of this is meant to suggest that democratic legitimacy rests entirely on the inclusivity of the demos; legitimacy involves more than this. In particular, the all-subjected principle says nothing about the decision procedures required for a legitimate democracy; nor does it specify the norms that should guide those procedures. However, the principle specifies

\footnotetext{
${ }^{35}$ Joseph Schumpeter, Capitalism, Socialism, and Democracy (Oxfordshire: Taylor and Francis, 1994), pp. 244-5. The new wave defenses of disenfranchisement are more sophisticated than this, because they target a particular set of individuals who, it may be argued, have forfeited their voting rights. Just as Schumpeter's argument for selfdetermination lacks the complexity of the new wave arguments, Dahl's response to Schumpeter must be significantly supplemented if it is to furnish a worthwhile critique of felon and prisoner disenfranchisement. I take up that work in $\S 3$ and $\S 4$.

${ }^{36}$ Dahl, Democracy and its Critics, p. 121. Robert Mickey has recently characterized these regimes as authoritarian enclaves in Paths out of Dixie: The Democratization of Authoritarian Enclaves in America's Deep South: 19441972 (Princeton: Princeton University Press, 2015).

${ }^{37}$ Dahl, Democracy and its Critics, p. 121.
} 
one necessary condition of legitimacy, which we can use as a diagnostic tool for assessing a demos: A democracy is more legitimate, all else held constant, the more it enables and protects the eligibility of its adult subjects to participate in democratic processes. To the degree that a democracy excludes qualified adult subjects from the franchise, it sacrifices some of the legitimacy that makes its official decisions binding on its subjects. Past a threshold, this loss of legitimacy may create problems for political obligation, the rule of law, and the polity's claims to be a genuine democracy. ${ }^{38}$ It can also undermine the validity of collective self-determination.

This suggests that the disenfranchisement policies that may be adopted in the name of democratic self-determination are, in fact, quite limited. A demos can decide all sorts of policies through the democratic process, and these policies will be binding upon members so long as democratic legitimacy is maintained. But disenfranchisement policies risk undermining legitimacy by excluding from the demos individuals who are subject to the law, thereby raising the ratio of 'rulers' to 'ruled'. On a case-by-case scale, this loss of legitimacy may be minor. However, when a democracy disenfranchises a large group or class of persons who, per the allsubjected principle, ought to be enfranchised, the loss of legitimacy can be serious. This is the case with existing felon and prisoner disenfranchisement policies in the United States, especially at state and local levels of democracy. By categorically excluding otherwise qualified subjects from the franchise, these policies undermine democracy's primary mechanism for giving equal consideration to its subjects and respecting their moral autonomy. Thus, felon and prisoner disenfranchisement policies undermine the legitimacy of democratic decision-making and, in turn, the normative significance of democratic self-determination.

\footnotetext{
${ }^{38} \mathrm{I}$ discuss these effects below, in $\S 4$.
} 
True, some democracies may be willing to accept this cost to legitimacy in exchange for other political goods, especially when the individuals excluded from the franchise are convicted offenders. However, the new wave defenses of disenfranchisement cannot accept this cost, because they justify felon and prisoner disenfranchisement in the name of democratic selfdetermination, and this is precisely what disenfranchisement undermines. To the extent that disenfranchisement policies violate the all-subjected principle of democratic inclusion, they erode the very value that Altman, Ramsay, and Sigler invoke to defend them. Thus, the new wave defenses of disenfranchisement seem to be self-defeating. ${ }^{39}$ They appeal to democratic decision-making to justify policies that undermine the normative force of democratic decisions.

\section{§3. Possible exceptions to the all-subjected principle}

If the argument of the previous section is compelling, then felon disenfranchisement policies have very tenuous philosophical justification, since they are an illegitimate mode of punishment, a problematic way of defining citizenship, and - as I am arguing — a self-defeating way to facilitate democratic self-determination. However, a lot depends on whether the allsubjected principle applies to felons and prisoners in the first place. Theorists generally recognize categorical exceptions to the principle for children, the severely mentally disabled, and non-citizen temporary residents, all of whom are commonly excluded from electoral

\footnotetext{
${ }^{39}$ It is helpful to clarify the conclusion I am anticipating here. I have argued that extensive disenfranchisement undermines democratic legitimacy by degrees (unless, as I discuss in the next section, the disenfranchised individuals constitute legitimate exceptions to the all-subjected principle). In practice, the potential antidemocratic effects of disenfranchisement are a matter of degree. The theoretical arguments defending these practices, however, risk wholesale incoherence insofar as (I will argue) they sacrifice the very value that they invoke for their justification. In the conclusion, I argue that the new wave arguments should be rejected on the basis of this incoherence; felon disenfranchisement practices, on the other hand, might be retained at a cost to democratic legitimacy — but theorists, activists, and politicians committed to democracy should be troubled by this compromise. Notably, this compromise is not available to Altman, Ramsay, Sigler, or others who invoke democratic ideals to defend what are, according to my argument, anti-democratic practices.
} 
participation. ${ }^{40}$ If felons and prisoners constitute similar exceptions to the all-subjected principle, then their disenfranchisement would not undermine democratic legitimacy. Here, I consider two sets of potential reasons for excluding felons and prisoners from the principle: the reasons underlying familiar exemptions for children, the severely mentally disabled, and non-citizen temporary residents; and reasons specific to criminal offenders and the conditions of imprisonment. I argue that none of them justify categorically exempting felons and prisoners from the all-subjected principle.

First, children are typically exempted from the all-subjected principle because they are not subject to the law in the same way as adults (their legal obligations differ), and they generally lack the experience and maturity necessary for informed and meaningful voting. Although the threshold between child and adult is blurry, and children may become qualified at younger ages than existing laws presume, the reasons for excepting young children from the the all-subjected principle are generally accepted. ${ }^{41}$ Nevertheless, these reasons do not widely apply to adult felons and prisoners. These individuals are subject to the law in the relevant ways, and generally they do not lack the experience or maturity necessary for meaningful voting. Neither felony

\footnotetext{
${ }^{40}$ Dahl, Democracy and its Critics, pp. 129-131. Each of these familiar exceptions is debatable, and in Democracy and Disenfranchisement, López-Guerra argues that they are unjustified in many cases.

${ }^{41}$ Nicholas Munn and López-Guerra both advocate lowering the age threshold for enfranchisement. Munn, "Reconciling the Criminal and Participatory Responsibilities of the Youth," Social Theory and Practice 38, no. 1 (2012): 139-159; López-Guerra, "Enfranchising Minors and the Mentally Impaired," Social Theory and Practice 38, no. 1 (2012): 115-138 and Democracy and Disenfranchisement, Ch. 3. More recently, Munn has suggested abandoning the capacity requirement altogether in "Against the Political Exclusion of the Incapable," Journal of Applied Philosophy, forthcoming, doi:10.1111/japp.12229. On the general issue of children's voting rights, see Beckman, Frontiers of Democracy, pp. 90-119; Andrew Rehfeld, "The Child as Democratic Citizen," Annals of the American Academy of Political and Social Science 633 (2011): 141-166; Robert Goodin and Joan Lau, "Enfranchising Incompetents: Suretyship and the Joint Authorship of Laws," Ratio 24, no. 2 (2011): 154-166; Philip Cook, "Against a Minimum Voting Age," Critical Review of International Social and Political Philosophy 16, no. 3 (2013): 439-458.
} 
status nor imprisonment corresponds to lack of capacity in the generalizable way that (young) childhood does.

The reasons for excepting persons with severe mental disabilities are more controversial. The presumption seems to be that persons with these disabilities lack the competence necessary to cast meaningful votes, which opens the possibility that their votes will impair the quality of electoral outcomes or be subject to manipulation by paternalistic guardians. However, LópezGuerra has convincingly argued that the threats of impaired electoral outcomes and manipulation are overstated, while Martha Nussbaum has argued that disenfranchising disabled voters violates fundamental commitments to equality and leads to an unacceptable slippery slope. ${ }^{42}$ These criticisms aside, even if we accept that some persons might be legitimately exempted from the all-subjected principle on the basis of incompetence, the incompetence would have to be severe and directly relevant to preference formation, decision-making, and political agency for this line of reasoning to be compelling. But there is no reason to think that felons or prisoners fit this description. To justify exempting them on these grounds, one would have to: clarify the relevant criterion of incompetence; show that felons and prisoners are generally, as a class, incompetent in the relevant ways; and show that non-felons and non-prisoners who are not exempt from the all-subjected principle are not incompetent in the relevant ways. I do not think this is possible

\footnotetext{
${ }^{42}$ López-Guerra, Democracy and Disenfranchisement, 62-68; Martha Nussbaum, "The Capabilities of People with Cognitive Disabilities," Metaphilosophy, 40, no. 3-4 (2009): 331-351 at pp. 343-350. See also Barbara Green and Nancy Klein, "The Mentally Retarded and the Right to Vote," Polity 13 (1980): 184-206; Ludvig Beckman, "Political Equality and the Disenfranchisement of People with Intellectual Impairments," Social Policy and Society 6, no. 1 (2007): 13-23 and Frontiers of Democracy, 146-166; López-Guerra, "Enfranchising Minors and the Mentally Impaired."
} 
without attributing a false homogeneity to felons and prisoners and seriously misdescribing their abilities. $^{43}$

The reasons for exempting short-term resident non-citizens from the all-subjected principle are more clear, but again, they generally do not apply to felons and prisoners, so long as they are citizens or permanent residents who would otherwise have the right to vote. Short-term residents, tourists, and visitors who are "passing through" a polity are not subject to the laws of the land in the same way as citizens and long-term residents, whose lives - and not merely their travels - are governed by the laws on an ongoing basis. ${ }^{44}$ But citizens convicted of felonies are subject to the law on an ongoing, long-term basis, and their lives are deeply constrained by the coercive power of the state. While particular exceptions might be argued on a case-by-case basis, generally felons and prisoners are not exempt from the all-subjected principle on these grounds. ${ }^{45}$ In sum, even if we accept the reasons for exempting children, severely mentally disabled persons, and temporary residents from the all-subjected principle, those reasons do not generally apply to felons and prisoners. The more interesting question is whether there are stronger reasons that are specific to criminal offenders or those held in prison. Although the new wave defenses of

\footnotetext{
${ }^{43}$ It is tempting to interpret incompetence in moral terms, as a lack of a sense of justice. Jean Hampton offers an argument of this kind, in a different context, in "Punishment, Feminism, and Political Identity." But even in moral terms, there are problems with this criterion; see note 61 below.

44 "The standard is plain: to be regularly subject to the legal system of a political unit," López-Guerra, Democracy and Disenfranchisement, p. 97. This criterion still requires some interpretation and refinement, but it provides a guiding principle. Notably, the all-subjected principle may give committed democrats reasons to endorse voting rights for permanent and long-term non-citizen residents, but this issue is beyond the scope of the current paper.

${ }^{45}$ It may be a consequence of my argument that non-citizens who are imprisoned within a democracy for a sufficient length of time should be granted voting rights in the jurisdictions where they are imprisoned. I welcome that consequence but cannot decide the issue here. From a democratic theory standpoint, it seems a straightforward application of the all-subjected principle. However, unique considerations may be relevant to this special case, and they might trump the all-subjected principle in ways that, I am arguing, do not obtain in cases of citizen imprisonment. Another special case would be non-citizen prisoners of war or imprisoned enemies of the state. Here, specific factors make the case even less like the case of imprisoned citizens. My initial intuition is that withholding voting rights in these cases does not cause a problem for democratic legitimacy.
} 
disenfranchisement are not framed in these terms, they contain several potential reasons for excepting felons and prisoners from the all-subjected principle. None, however, are decisive.

One possible ground for exemption is implicit in Ramsay's argument that incarcerated individuals are so tightly administered by the state that they ought to be disenfranchised to protect the integrity of the democratic process. While incarcerated, prisoners are dependent on correctional institutions for their basic living conditions, while their access to information, ability to communicate and express political views, and rights to associate are severely curtailed by the state. According to Ramsay, this means that prisoners lack the civil liberties necessary to "formulate views that are authentically their own" and participate meaningfully in the democratic process. ${ }^{46}$ If this is correct, then it may be sufficient reason to exempt currently incarcerated persons from the all-subjected principle.

However, the assumptions behind Ramsay's argument are flawed. Imprisonment is not equivalent to brainwashing, and the writing, online media, political organization, and everyday conversations of prisoners show that independent thinking, autonomous preference-formation, and political deliberation do not automatically die behind bars. ${ }^{47}$ Moreover, even individuals in maximum security units continue thinking, writing, and even organizing, both to ameliorate the

\footnotetext{
${ }^{46}$ Ramsay, "Voters Should Not Be in Prison," pp. 425-6.

${ }^{47}$ Upon sentencing Antonio Gramsci, the public prosecutor allegedly said, "For twenty years we must stop this brain from working." The development of Gramsci's political theory in prison shows that this failed. Gramsci, Selections from the Prison Notebooks, ed. Hoare and Smith (New York: International Publishers, 2003), lxxxix. Other works that disprove Ramsay's assumptions include George Jackson's Soledad Brother (Chicago: Chicago Review Press, 1994), Jack Henry Abbot's In the Belly of the Beast (New York: Vintage, 1991); the poetry of Marilyn Buck, the radio journalism of Mumia Abu-Jamal, and the essays of Russell Maroon Shoatz. See also Judith Scheffler, ed., Wall Tappings: An International Anthology of Women's Prison Writings, 200 to the Present (New York: Feminist Press at CUNY, 2002) and Doran Larson, ed., Fourth City: Essays from Prison in America (East Lansing: Michigan State University Press, 2014).
} 
conditions of their own confinement and to continue engaging with the outside world. ${ }^{48}$ As a class, then, prisoners do not lack the intellectual and political autonomy necessary to participate in democratic self-determination; indeed, their political preferences may be more "authentically their own" than those of many voters on the outside. Thus, Ramsay's argument offers no good reason for categorically exempting currently incarcerated prisoners from the all-subjected principle.

Alternatively, it might be argued that felons and prisoners can be exempted from the principle because they voluntarily consent to disenfranchisement as an administrative consequence of their criminal offenses. This reasoning resembles social contractarian arguments for disenfranchisement, which have been widely criticized on several grounds. First, the contractarian emphasis on voluntarism and rational choice severely limits the scope of cases to which this reasoning might be applied. Second, the contractarian model is ill-suited to real-world societies characterized by background injustices, which are directly relevant to crime and sentencing. Third, most felony offenses are not tantamount to breaking the social contract, and disenfranchisement is not tantamount to a full loss of civil rights, so disenfranchisement policies do not fit the justificatory framework of classical contractarian models. ${ }^{49}$ More generally, contract theory does not explain why felons or prisoners should lose their voting rights, in particular, but not the other rights which they retain in prison or after release.

\footnotetext{
${ }^{48}$ For example, in 2013, individuals held in solitary confinement in California's Pelican Bay State Prison coordinated a statewide hunger strike that involved 30,000 prisoners and their outside allies.

${ }^{49}$ For versions of these criticisms, see Reiman, "Liberal and Republican Arguments," pp. 9-13; Schall, "The Consistency of Felon Disenfranchisement with Citizenship Theory," pp. 73-83; López-Guerra, Democracy and Disenfranchisement, pp. 110-12. There may be arguable exceptions for a subset of offenses that related directly to electoral participation, such as voter fraud.
} 
Apart from these criticisms, it can be added that the most successful branch of contemporary contractarianism, hypothetical consent theory, can at best justify the basic structures of society, but not the details of its legal code or sanctions for particular offenses. ${ }^{50}$ Individuals do not explicitly, tacitly, or even hypothetically consent to disenfranchisement as an administrative consequence of a felony conviction or prison sentence. Even if they did, it is not clear that their consent would justify abrogating the all-subjected principle. One does not have to be a skeptic about the assumptions of contract theory to acknowledge that not all contracts are valid, and that distinguishing between valid and invalid contracts requires appeal to something other than consent alone. As Joseph Raz writes in another context, "Consent does not solve the problem. It can solve the problem only when there is a reason for such consent to bind us," and a reason that can do this work will obviate the role of consent in the first place. ${ }^{51}$ The reason that does this work is usually a broadly Kantian respect for the rational autonomy of individuals. ${ }^{52}$ But this is an underlying reason that justifies self-determination and enfranchisement in a democratic polity. Thus, it is unclear how consent could trump the all-subjected principle, because both are vehicles for the same fundamental good-rational autonomy - and at best, consent can only justify the basic structures of a political association, while democratic decisionmaking justifies particular laws and sanctions.

Finally, Sigler's account of "defensible disenfranchisement" contains a third possible argument for exempting felons and prisoners from the all-subjected principle. Sigler argues that self-determination in a liberal democracy requires civic trust between members. Individuals must

\footnotetext{
${ }^{50}$ Rawls, Theory of Justice, pp. 6-10.

${ }^{51}$ Joseph Raz, Between Authority and Interpretation (Oxford: Oxford University Press, 2009), p. 161.

${ }^{52}$ On hypothetical consent as a vehicle for rational autonomy, rather than voluntary choice, see Cynthia Stark, "Hypothetical Consent and Justification," Journal of Philosophy, 97, no. 6 (2000): 313-334 at pp. 333-4.
} 
see themselves as part of the same polity, and fulfill the duties specific to members of that polity, in order for collective self-determination to be effective. ${ }^{53}$ Members who commit certain kinds of crimes, such as serious felonies, might be said to disrupt this civic trust. Extending this logic, one might argue that when individuals commit trust-violating acts, they show themselves to be neglecting their civic duties, and this makes it legitimate to exempt them from the all-subjected principle.

However, civic trust is a slippery concept, especially in contexts of criminalization and electoral exclusion. In the United States, the connected histories of felon disenfranchisement, Black Codes, and Jim Crow laws demonstrate how prejudice shapes not only popular ideas, but even juridical definitions, of who is civically untrustworthy (or "infamous") and therefore subject to disenfranchisement. ${ }^{54}$ Aware of this history, Sigler narrows the concept of civic trust in order to refine its meaning, clarify its link to electoral participation, and dissociate it from prejudicial forms of exclusion. She writes, "Civic trust is itself a duty of citizenship and describes the baseline expectation that other citizens are fulfilling the responsibilities of their office." They do this by "taking account of the public good when exercising their right to voteand by trusting that others will do the same." $" 55$ On this narrowed account, it is clear how

\footnotetext{
${ }^{53}$ Sigler "Defensible Disenfranchisement," pp. 1733-8.

${ }^{54}$ In the U.S., the concept of criminal "infamy" enabled felon disenfranchisement to be used to undercut the civic status of freed slaves after the Civil War, and then African Americans and other minorities more generally. For recent studies, see Khalil Muhammad, The Condemnation of Blackness: Race, Crime and the Making of Modern Urban America (Cambridge: Harvard University Press, 2011); Pippa Holloway, Living in Infamy: Felon Disenfranchisement and the History of American Citizenship (Oxford: Oxford University Press, 2014).

${ }^{55}$ Sigler, "Defensible Disenfranchisement," p. 1736.
} 
violations of trust relate to disenfranchisement, since violations demonstrate that one is unable or unwilling to perform his or her specifically political duties qua citizen. ${ }^{56}$

However, this more specific account of civic trust cannot justify a categorical exemption for felons and prisoners from the all-subjected principle, because while civic trust is now more tightly connected to issues of electoral eligibility, it is not sufficiently connected to felony convictions or imprisonment. We can see this by considering the way that the argument becomes both over-inclusive and under-inclusive once the narrower account of civic trust is introduced. It is over-inclusive because individuals convicted of serious felonies might still fulfill the duties that are specific to citizens, since many felonies bear no correlation to the particular responsibilities, like voting with the public interest in mind, that are central to Sigler's account. But more revealingly, the argument is under-inclusive because there are many ways to violate civic trust without being convicted of a felony. This is not because many criminal offenders are not convicted, but because many violations of civic trust do not involve criminal offenses at all. In fact, individuals regularly violate civic trust in Sigler's specific sense, through acts that are directly related to their responsibilities as citizens, but which bear no link to felony offenses. Consider a self-interested voter who ignores the public good, a campaign advisor who values victory for his or her candidate above all else, a racist voter whose political preferences are defined by prejudice, and a political cynic who abstains from voting because he or she believes elections are rigged. All of these persons undermine civic trust according to Sigler's narrower definition, but they do so without committing one of the serious felonies that her argument

\footnotetext{
56 "The right to vote is the relevant currency to mark the breach of [this form of] civic trust because, unlike criminal punishment, voting is linked directly to citizenship and the rights and responsibilities of that office." Ibid., pp. 17378.
} 
targets. This shows that civic trust, felonies, and electoral participation are not aligned in the way that Sigler's argument requires. ${ }^{57}$

At best, Sigler's argument justifies exempting serious violators of civic trust from the all-subjected principle, but this is not an argument for categorically exempting felons or prisoners. An advocate for her view might respond that the loose connection to felonies and imprisonment does not matter, since in practice we aren't assessing everybody's eligibility to vote, just the eligibility of the convicted felons whose statuses are already in the hands of judges. But this begs an issue that Sigler wants to avoid: the practical realities, including race- and classbased injustices, that greatly determine who gets convicted of serious felonies and who does not, at least in the United States. In addition to shaping who is subject to felon and prisoner disenfranchisement, these realities should also shape how we punish and what expressive messages our punishments convey. ${ }^{58}$ To set these issues aside, Sigler focuses on principle rather than practice. ${ }^{59}$ That move is valid for her purposes, but it forecloses an obvious way to address the under-inclusiveness of her argument. Focusing on principle rather than practice, she needs a principled way to align felony convictions, civic trust, and electoral participation, but she does not provide one. ${ }^{60}$

\footnotetext{
${ }^{57}$ To be clear, the problem is not merely the over- and under-inclusiveness of the argument. Rather, these characteristics reveal that the argument lacks a principled way to connect violations of civic trust, in Sigler's specific sense, to the conditions of felony status or imprisonment, without sacrificing the connection between civic trust and electoral eligibility. Thus, the argument does not explain all that it needs to.

${ }^{58}$ Richard Lippke, "Diminished Opportunities, Diminished Capacities: Social Deprivation and Punishment," Social Theory and Practice 29, no. 3 (2003): 459-485.

${ }^{59}$ Sigler, "Defensible Disenfranchisement," p. 1728.

${ }^{60}$ Jean Hampton offers a similar defense of disenfranchisement. For Hampton, some offenders may be disenfranchised in order to send them a morally educative message about a society's values. Hampton specifies that this only applies to offenders whose crimes carry political significance or challenge the values of a democratic society, because these offenders, presumably, lack a sense of justice that disenfranchisement's morally educative message might engender. See Hampton, "Punishment, Feminism, and Political Identity." However, Hampton's argument is vulnerable to roughly the same criticisms as I have raised against Sigler's. Additionally, her argument
} 
In sum, felons and prisoners do not constitute legitimate exceptions to the all-subjected principle of democratic inclusion. The above review of reasons cannot be exhaustive, but it demonstrates the difficulty of justifying categorical exemptions for persons previously convicted of serious crimes or currently serving time in prison. The reasons behind widely recognized exemptions to the all-subjected principle, such as those for young children, severely mentally disabled persons, and non-citizen temporary residents, do not generally apply to these cases. Moreover, the strongest arguments for felon and prisoner disenfranchisement also fail to provide reasons for exempting these persons from the all-subjected principle. Granted, those arguments may justify barring certain felons or certain prisoners from the principle on a case-by-case basis. In general, however, adult felons and prisoners who are subject to democratic law on an ongoing basis ought to be included in the democratic decision-making processes that generate, direct, authorize, and check that law. Their eligibility for the franchise is necessary, although not sufficient, for the state to give them equal consideration before the law, respect their autonomy, and legitimate its own laws and policies through democratic decision-making procedures.

\section{$\S 4$. The democratic costs of disenfranchisement}

When a democratic state disenfranchises numerous individuals who, per the all-subjected principle, ought to be included in collective processes of decision-making, that state undercuts its own democratic legitimacy, and thereby undermines its own acts of democratic selfdetermination. A democracy that disenfranchises felons and prisoners does just that. In an era of so-called mass incarceration, disenfranchisement policies like those enforced by the majority of

remains vague about how disenfranchisement accomplishes, or is a necessary condition for, the moral education that Hampton advocates. For other critiques of Hampton's position, see Beckman, Frontiers of Democracy, pp. 137-9. 
U.S. states create large populations of "semi-citizens" or internal outsiders who are locked out of the democratic process. ${ }^{61}$ Particular individuals may move into and out of the disenfranchised population as their voting rights are suspended and restored-in states where restoration is even possible - but what matters for democratic legitimacy is the persistence of the population itself. Especially at state and local levels, the size of disenfranchised populations can be electorally significant, and this has serious consequences for democratic legitimacy.

This, then, is the common flaw in the new wave defenses of disenfranchisement: By advocating policies that undermine democratic legitimacy, they ultimately undercut the political value that they invoke for justification. This does not mean that legitimacy totally vanishes when felon disenfranchisement policies are enacted. Rather, it means that these policies come with a cost, and this cost is born not only by persons excluded from the franchise, but also by the enfranchised persons who make up the demos. In practice, some democracies may be willing to bear this cost to legislative and legal legitimacy. But the 'new wave' defenses of disenfranchisement cannot accept this cost, because it drains normative significance from the political value on which their defense rests. At the level of theory, arguments that defend felon and prisoner disenfranchisement in the name of democratic self-determination are self-defeating. At the level of practice, disenfranchisement policies have antidemocratic effects that committed democrats should not be willing to accept.

What follows from this loss of democratic legitimacy? At minimum, the policies decided by a restricted demos become more difficult to justify with reference to democratic values. Past a certain threshold of disenfranchisement, it is misleading to claim that those policies reflect the

\footnotetext{
${ }^{61}$ On "semi-citizen" status, see Elizabeth Cohen, Semi-Citizenship in Democratic Politics (Cambridge: Cambridge University Press, 2009) and Elizabeth Anderson, “Outlaws,” The Good Society, 23, no. 1 (2014): 103-113.
} 
will of the people, or that the decision process has given equal consideration to all citizens who wish to provide their input. But it is important to remember that democratic decision-making is not, generally speaking, a referendum. Voters do not typically vote up or down particular policies. Rather, they choose the representatives, broad policy platforms, and the major expressions of political values and priorities that will define a particular administration or legislative session. Disenfranchisement, especially when it is highly concentrated in particular districts, alienates the disenfranchised from that regime and from their fellow citizens. Moreover, extensive disenfranchisement requires enfranchised citizens to make regime-defining choices for the disenfranchised, and this intensifies heteronomy and paternalism that belie the regime's democratic character. Finally, the loss of democratic legitimacy may, if it is severe, undermine the rule of law by attenuating subjects' obligation to obey legislation. The philosophical debates on political obligation are too complex to pursue here. However, on theories that locate the duty to obey the law in democratic political participation itself — or, more plausibly, in any associative duties or natural duties that require equal political participation to be dischargeddisenfranchisement's constriction of the demos will weaken the normative 'glue' that binds subjects to the law.

Importantly, the antidemocratic effects of disenfranchisement do not impact only the individuals who are barred from the franchise, but all subjects who have a stake in the legitimacy, democratic character, and lawfulness of their regime. This distinguishes the argument developed here from other critiques that focus only on how disenfranchisement affects the disenfranchised. For example, López-Guerra has argued that electoral exclusion unjustly harms the excluded, at least in many cases. ${ }^{62}$ The problem with this critical strategy is that the new

\footnotetext{
${ }^{62}$ Democracy and Disenfranchisement, Ch. 2, 3, 5 .
} 
wave defenses of disenfranchisement contain an implicit but comprehensive reply, insofar as their arguments are couched in terms of collective, not merely individual, political goods. The potential reply makes three moves: first, arguing that disenfranchisement's harms to some individuals are justified by their past actions (criminal offenses); second, arguing that the harms to individuals are outweighed by the benefits of democratic self-determination for the entire demos; and third, introducing constraints on disenfranchisement (such as time limits) or compensatory measures to ensure that the harms to disenfranchised individuals are not excessive. This reply causes problems for López-Guerra's argument, but it cannot be used against the argument I have advanced here, because my argument does not construe the problem with disenfranchisement in terms of harms to the disenfranchised or in terms of individual moral claims. ${ }^{63}$ Rather, my critique of the new wave arguments engages them on their own collectivist terms. On my view, the problem with disenfranchisement is a problem for democracy itself, and the erosion of democratic legitimacy negatively affects all persons who are governed by a democracy's legal system, regardless of their eligibility to vote. For the disenfranchised persons who are merely subject to democratic rule, and for the enfranchised members of the demos who indirectly participate in democratic rule, felon and prisoner disenfranchisement undermines the legitimacy of the democratic laws that govern them all. Thus, my argument offers a way of out the argumentative impasse described in $\S 1$ by aligning, rather than opposing, the claims of disenfranchised individuals and those of the demos. In the name of democracy, disenfranchised

\footnotetext{
${ }^{63}$ In addition to its antidemocratic effects, felon and prisoner disenfranchisement may also be an injustice toward the disenfranchised. There is nothing inconsistent in affirming the democratic critique I have advanced here and the liberal justice critique articulated by López-Guerra, so long as the latter can overcome the challenges raised by the new wave defenses of disenfranchisement. I am skeptical that it can, however. Liberal justice critics of disenfranchisement should supplement their arguments with the democratic theory critique I raise here.
} 
and enfranchised subjects share reasons for rejecting felon and prisoner disenfranchisement policies.

Thus far, I have advanced two main arguments. First, I have argued that the new wave defenses of disenfranchisement fail because they appeal to democratic values that are undermined by the very policies they seek to justify. Relatedly, I have argued that felon disenfranchisement practices impose costs to democratic legitimacy-costs born by all subjects of a democracy — which committed democrats should be unwilling to accept. Before concluding, several aspects of these arguments need clarification.

First, it might be objected that my arguments are, at bottom, arguments for the inalienability of voting rights. If this is the case, then one might wonder why voting rights are inalienable while other important rights — such as rights to free movement, speech, and assembly — can be justifiably restricted by the state, as in situations of imprisonment. ${ }^{64}$ In response, I want to clarify that my arguments do not commit me to the inalienability of voting rights (or to the permissibility of restricting other rights via imprisonment). To seriously consider the new wave defenses of disenfranchisement, one has to grant that voting rights can be alienated in certain circumstances, and I have accepted this in principle. However, it is a different question whether a felony conviction or imprisonment are grounds for restricting the right to vote. I do not believe they are, for reasons articulated in $\S 3$. Generally speaking, there is no normative link between criminal conviction and electoral participation that is sufficiently robust to trump the all-subjected principle of democratic inclusion-at least, none that justifies categorically disenfranchising felons or prisoners. And, as I have argued in $\S 4$, there are strong reasons,

\footnotetext{
${ }^{64}$ I thank Thom Brooks for pressing me to clarify this issue.
} 
relevant to widely-held democratic values, for not stripping felons and prisoners of their voting rights.

It remains an open question whether other political rights, such as free movement, assembly, and speech, are as vital to democratic legitimacy as the right to vote. If they are, then imprisonment itself may have antidemocratic effects that should concern committed democrats. ${ }^{65}$ But defenders of imprisonment might argue that the relevant trade-offs are different with regard to these rights, insofar as their restriction may be justified by normative theories of punishment or security concerns. ${ }^{66}$ I cannot enter those debates here, except to say that similar claims cannot be made about voting rights. The right to vote may be no more inviolable than other rights, but there is no compelling justification for categorically stripping it from felons and prisoners, especially in light of disenfranchisement's costs to democratic legitimacy. The importance of democratic self-determination is not a coherent justification, for reasons I have articulated.

Second, it could be asked whether felon and prisoner disenfranchisement negatively impacts other collective goods, beyond democratic legitimacy. That may be so. I have highlighted disenfranchisement's costs to legitimacy because this good underlies Altman's, Ramsay's, and Sigler's emphasis on democratic self-determination, and this gives the argument its critical bite against the most recent and strongest defenses of disenfranchisement. But disenfranchisement may have other antidemocratic effects, such as undercutting epistemically valuable forms of voter pluralism, contributing to unjustified social hierarchy, and intensifying

\footnotetext{
${ }^{65}$ See Angela Davis, The Meaning of Freedom and Other Difficult Dialogues (San Francisco: City Lights Books, 2012); Traci Burch, Trading Democracy for Justice: Criminal Convictions and the Decline of Neighborhood Political Participation (Chicago: University of Chicago Press, 2013); Amy Lerman and Vesla Weaver, Arresting Citizenship: The Democratic Consequences of American Crime Control (Chicago: Chicago University Press, 2014).

${ }^{66}$ Even those arguments face powerful difficulties. For instance, Richard Lippke argues that normative punishment theory justifies the conclusion that prisoners should retain many of the rights of free citizens, and in fact that punitive institutions should facilitate those rights. See Lippke, Rethinking Imprisonment (Oxford: Oxford University Press, 2007), 196-209.
} 
civic alienation. If any of these possibilities are actual, then not only the persons excluded from the franchise, but also the enfranchised voters who intend their votes to count in a meaningful democratic process could all stand to lose from disenfranchisement. Of course, these claims require empirical and theoretical analyses that are beyond the scope of this article. Nevertheless, this article highlights how such analyses might contribute to theoretical debates. Specifically, it shows how and why critics of disenfranchisement should focus on collective political goods as well as individual interests. Other critics are not wrong to highlight the unjust harms that fall uniquely on disenfranchised individuals. However, in order to respond to the strongest defenses of disenfranchisement, we need to examine the antidemocratic costs that may be born by all democratic stakeholders.

Finally, it should be noted that the argument developed here specifies a baseline cost to democratic legitimacy, which varies with the proportion of the disenfranchised population in comparison to the demos. The cost may be even more severe when disenfranchisement falls disproportionately on minorities or marginalized members of society, as it does in many U.S. states, especially Alabama, Kentucky, and Florida, where one in five African-American adults are disenfranchised. However, this claim would require more argumentation than I can provide here. Differential impact has not been my focus, because I have sought to respond to recent defenses of disenfranchisement in their own idealized terms. Therefore, I have assessed the baseline impacts on democratic legitimacy when significant populations of otherwise qualified subjects of democratic law are barred from the demos, no matter who those qualified subjects are. 
Whitt, Felon Disenfranchisement and Democratic Legitimacy, 35

\section{§5. Conclusion}

This article has made two contributions to theoretical debates on felon and prisoner disenfranchisement. First, it has responded to the most recent and strongest defenses of disenfranchisement, which seek to justify electoral exclusion in the name of democratic selfdetermination. These defenses are immune to traditional critiques that approach disenfranchisement as a form of punishment or a mode of regulating citizenship. Meeting the new defenses on their own terms, I have argued that felon and prisoner disenfranchisement undermine the legitimacy of democratic decision-making. Thus, these forms of electoral exclusion cannot be procedurally or instrumentally justified in the name of democratic selfdetermination. In short, the 'new wave' arguments fail because they defend policies that betray their own core commitments.

Second, the article has identified and overcome a previously unacknowledged problem in otherwise compelling critiques of disenfranchisement, like the one offered by López-Guerra. By focusing on the ways that disenfranchisement harms individuals who are excluded from the demos, these critiques fall into an argumentative impasse, in which the rights of disenfranchised individuals are pitted against the prerogative of the demos to determine the conditions of its own political association, with no clear way to resolve these competing claims. My argument takes a different tack, by analyzing the negative impact of disenfranchisement on all who are governed by a democratic regime, disenfranchised individuals and members of the demos alike. This is not meant to replace justice-focused critiques that highlight the harms of disenfranchisement to disenfranchised individuals. However, my democracy-focused argument provides a necessary supplement to those critiques, by overcoming a line of objection for which they have no response. 
Beyond academic debates, in public political discourse, it is not uncommon for avowed democrats to champion significant restrictions of the demos in the name of securing democracy. This article has shown why their justifications ring hollow. Aside from other potential undemocratic effects of disenfranchisement — such as creating hierarchy among residents, entrenching divisions within the population, or undermining the epistemic benefits of voter pluralism - restricting the circle of persons who make legislation, relative to those who must take it, undercuts the legitimacy and normative significance of democratic self-determination. Democracy is eroded, not secured, by policies that exile voters from the demos while retaining them as subjects of the state. 